\title{
Soybean Stem Colonization by Genotypes A and B of Cadophora gregata Increases with Increasing Population Densities of Heterodera glycines
}

\author{
G. M. Tabor, G. L. Tylka, and C. R. Bronson, Department of Plant Pathology, Iowa State University, Ames 50011
}

\begin{abstract}
Tabor, G. M., Tylka, G. L., and Bronson, C. R. 2006. Soybean stem colonization by genotypes A and B of Cadophora gregata increases with increasing population densities of Heterodera glycines. Plant Dis. 90:1297-1301.

Growth chamber experiments were conducted to investigate whether parasitism by increasing population densities of Heterodera glycines, the soybean cyst nematode, increases the incidence and severity of stem colonization by the aggressive genotype A and the mild genotype B of Cadophora gregata (Phialophora gregata), causal agents of brown stem rot of soybeans. Soybean genotypes with three combinations of resistance and susceptibility to $H$. glycines and genotype A of $C$. gregata were inoculated with each genotype of $C$. gregata alone or each genotype with two population densities of $H$. glycines eggs, 1,500 or 10,000 per $100 \mathrm{~cm}^{3}$ of soil. Stems of two $H$. glycines-susceptible soybeans were more colonized by both aggressive and mild genotypes of $C$. gregata in the presence of high than in the presence of low $H$. glycines population density.
\end{abstract}

Additional keywords: disease progress, pathogen interaction, soilborne

Brown stem rot (BSR) is a widespread (25) and economically important disease of soybeans (Glycine max (L.) Merr.) in the north-central United States. It is caused by the vascular pathogen Cadophora gregata Harrington \& McNew (5) (Phialophora gregata (Allington \& D.W. Chamberlain) W. Gams (AC)) (1). The soybean cyst nematode, Heterodera glycines Ichinohe, is also economically important and widely distributed throughout the midwestern United States (25).

Annual yield loss estimates for the United States from 1999 to 2002 ranged from 188,038 to 315,899 metric tons for BSR and from 3,605,962 to $4,299,382$ metric tons for the soybean cyst nematode (SCN) (26). The current recommended management strategy for both pathogens is the use of resistant soybean cultivars combined with rotation to nonhost crops (17,23,24,27). In the Midwest, Cadophora gregata is composed of two genotypes $(3,6)$ that differ in their aggressiveness and ability to cause BSR symptoms on certain soybean genotypes $(6,8)$. Genotype $\mathrm{A}$ is generally recognized as the more aggressive based on symptom expression on soybeans without known BSR resistance genes $(3,6,8)$. However, it is not known which genotype of the fungus causes the

Corresponding author: G. M. Tabor

E-mail: gtabor@iastate.edu

Accepted for publication 30 May 2006.

DOI: 10.1094/PD-90-1297

(C) 2006 The American Phytopathological Society most yield loss in soybeans. Both genotypes of the BSR fungus are widely found in the north-central United States (6).

The effect of $H$. glycines on increasing incidence and severity of BSR stem symptoms has been reported $(12,18,19,22)$. In 2003, Tabor et al. (19) reported that $H$. glycines not only increases incidence and severity of BSR stem symptoms but also increases incidence and severity of stem colonization by genotype A of $C$. gregata. They also reported that infection by $H$. glycines breaks resistance to genotype A in many BSR-resistant soybeans (19). Whether $H$. glycines increases incidence and severity of stem colonization by genotype B of C. gregata is yet to be investigated.

The timing of infection by $C$. gregata may be important in determining yield loss. Difference in the timing of colonization by the fungus appears to be an important difference between genotype Aresistant and genotype A-susceptible soybeans. Tabor et al. (20) demonstrated in growth chamber experiments that stems of the genotype A-susceptible cultivar Sturdy were colonized earlier than stems of the genotype A-resistant cultivar BSR101. In the presence of $H$. glycines, C. gregataresistant soybean cultivars may be colonized by the fungus as early as genotype A-susceptible cultivars are colonized by the fungus in the absence of $H$. glycines.

Infection by $H$. glycines is known to affect the progression of colonization of soybean stems by $C$. gregata. In growth chamber experiments using genotype A of C. gregata and one population density of H. glycines, Tabor et al. (19) have shown that $H$. glycines can cause earlier colonization of soybean stems by genotype A of $C$. gregata. Thus, the potential of various population densities of $H$. glycines to affect the progression of colonization of soybeans by both genotypes of $C$. gregata should be determined.

The objective of this research was to determine if increasing population densities of $H$. glycines affect the colonization of soybean stems by genotypes $\mathrm{A}$ and $\mathrm{B}$ of $C$. gregata over time.

\section{MATERIALS AND METHODS}

Three growth chamber experiments (experiments $1 \mathrm{~A}, 1 \mathrm{~B}$, and $1 \mathrm{C}$ ) were conducted to determine the effect of $H$. glycines on colonization of stems by $C$. gregata over time in genotype A-resistant and genotype A-susceptible soybean cultivars.

Soybean cultivars. The soybean cultivars tested in the three experiments were the genotype A-resistant and SCNsusceptible BSR101 (21), the genotype Aand SCN-susceptible Sturdy (16), and the genotype A- and SCN-resistant Jack (14). Seeds of each genotype were planted in an autoclaved mix of sand and soil (1:1) in 4 $\times 21 \mathrm{~cm}$ plastic, cone-shaped containers (Stuewe and Sons, Corvallis, OR). There was one plant per container, and plants were grown in a growth chamber at a constant temperature of $22^{\circ} \mathrm{C}$. In all experiments, plants were grown under $16 \mathrm{~h}$ light and were fertilized weekly.

H. glycines inoculum production. $H$. glycines was increased on $H$. glycinessusceptible Kenwood 94 soybeans in a greenhouse. Eggs were obtained by dislodging female nematodes and cysts from roots of infected plants with a stream of water, and wet-sieving and decanting $(4,13)$ of $H$. glycines-infested soil. Females and cysts were recovered on a 250 $\mu \mathrm{m}$-pore sieve nested below an $850-\mu \mathrm{m}$ pore sieve. Eggs were released from females and cysts by crushing them in water with a motorized pestle (13), and eggs were collected on a 25- $\mu \mathrm{m}$-pore sieve nested under a 75- $\mu \mathrm{m}$-pore sieve. Eggs were separated from plant debris and soil particles by centrifugal flotation (9) and counted by direct microscopic observation. Inoculum population densities used in the experiments were $0,1,500$, and 10,000 $\mathrm{H}$. glycines eggs per plant.

C. gregata inoculum production. Genotype A of $C$. gregata strain (OH2-3) used in the study (19) was a single-spore isolate of strain $\mathrm{OH} 2$ provided by Cecil 
Nickell at the University of Illinois. Genotype B, 98A5-6, (8) was provided by Craig Grau at the University of WisconsinMadison. The genotypes of the isolates were confirmed by the molecular method used by Chen et al. (3) and by comparing the distinct colony morphology of each isolate on green bean extract (GBE) medium (35 g of ground frozen Phaseolus vulgaris L. green pods and $20 \mathrm{~g}$ of agar per liter). Cultures were started on GBE medium supplemented with $50 \mathrm{mg}$ of ampicillin per liter and were incubated at room temperature $\left(21\right.$ to $\left.23^{\circ} \mathrm{C}\right)$ until abundant sporulation was evident. Conidia were suspended in sterile deionized water, mixed with twice-autoclaved, shredded soybean straw, and incubated for 25 to 30 days at room temperature in the dark. The number of $C$. gregata colony forming units (CFU) per gram of straw inoculum was determined by serial dilution and plating on GBE agar.

Inoculation and incubation. In all experiments, inoculum was incorporated into an autoclaved mix $\left(100 \mathrm{~cm}^{3}\right)$ of equal volumes of sand and soil. The soil and inoculum mix was placed in $4 \times 21 \mathrm{~cm}$ plastic, cone-shaped containers before planting of soybean seeds. Pathogen treatments per $100 \mathrm{~cm}^{3}$ of soil were genotype A alone, genotype $\mathrm{A}+1,500 \mathrm{H}$. glycines eggs, genotype $\mathrm{A}+10,000 \mathrm{H}$. glycines eggs, genotype $\mathrm{B}$ alone, genotype $\mathrm{B}+1,500 \mathrm{H}$. glycines eggs, genotype $\mathrm{B}+10,000 \mathrm{H}$. glycines eggs, and 10,000 $\mathrm{H}$. glycines eggs alone as a negative control (not included in experiment 1A). The $H$. glycines-only treatments received equal amounts of twice-autoclaved, $C$. gregata-free shredded straw. Plants were grown in a growth chamber at a constant temperature of $22^{\circ} \mathrm{C}$ and $16 \mathrm{~h}$ light. Colonization of stems by $C$. gregata was monitored over time and plants were sampled repeatedly from 4 to 12 weeks. The $C$. gregata inoculum population densities used in each of the experi- ments is listed in the tables and figure legends.

Experimental design. In all experiments, containers were arranged in a randomized complete block design, and blocks were locations in the growth chamber. In all experiments, there were four blocks, and a treatment combination occurred once per block and comprised one plant in a container.

Incidence and severity assays. To assess percentage of stems colonized and severity of stem colonization, stems were severed at the soil line and were immersed for $3 \mathrm{~min}$ in $70 \%$ ethanol, followed by 5 min in $0.5 \%$ sodium hypochlorite and a final rinse in sterile, deionized water. Stem length was measured, and the stems were cut into 2-cm-long pieces. The pieces were plated on GBE agar supplemented with ampicillin (50 mg/liter) and incubated at $15^{\circ} \mathrm{C}$ in the dark for 15 days. The emerging fungal mycelia were examined microscopically for conidia and conidiophores with morphology characteristic of $C$. gregata. A stem (plant) was considered colonized if $C$. gregata was recovered from any portion of the stem piece. In all instances, stems were colonized starting from the base up to the maximum height colonized without gaps. Consequently, severity of colonization was calculated by dividing the maximum height colonized by the total stem height. The genotypes of the isolates were confirmed by the molecular method used by Chen et al. (3) and also by their distinct colony morphology on GBE medium. Colonization data were collected without knowledge of the treatments.

Data analyses. All statistical analyses were conducted using the SAS software package version 9.1 (SAS Institute, Cary, NC). Results from the three experiments were similar, and thus, data were pooled. For each experiment, data on incidence and severity of $C$. gregata colonization over time were converted to area under disease progress curve (AUDPC) using (2) the formula:

$$
\mathrm{AUDPC}=\sum_{i=1}^{n-1}\left[\left(X_{i}+X_{i+1}\right) / 2\right]\left[t_{i+1}-t_{i}\right]
$$

in which $X_{i}=$ disease incidence or severity expressed as a percentage of the $i$ th observation, $t_{i}=$ time (weeks after planting) at the $i$ th observation, and $n=$ total number of observations. AUDPC data were analyzed using the mixed model (10) analysis of fixed effects (Mixed Procedure) treating experiments and blocks as random effects and pathogen as a fixed effect. For each cultivar, orthogonal comparisons were made among pathogen treatment means. To determine whether it is the time (intercept) or the rate (slope) of the progression of colonization affected by $H$. glycines, data on incidence and severity of $C$. gregata colonization over time were analyzed by logistic regression (7) using the Logistic procedure. Chi-square analysis was used to test slope and intercept differences of the regression of $C$. gregata colonization over time between pathogen treatments within a soybean genotype.

\section{RESULTS}

Analyses of data using AUDPC and logistic regression suggest that, in some cultivars, the incidence and/or severity of colonization by both genotypes of $C$. gregata increased with increasing population densities of $H$. glycines.

AUDPC. Genotype A. As population densities of $H$. glycines increased, the incidence and severity of stem colonization by genotype A of $C$. gregata increased $(P<$ $0.001)$ in Sturdy and BSR101 but not $(P>$ 0.10 ) in Jack (Table 1).

Genotype B. As population densities of $H$. glycines increased, the incidence and severity of stem colonization by genotype B of $C$. gregata increased $(P<0.001)$ in Sturdy and BSR101. For Jack, there was a trend $(P \leq 0.10)$ of increased colonization

Table 1. Colonization of soybean stems by genotypes A and B of Cadophora gregata $(C . g$.) in the presence three population densities of $H$. glycines $(H . g$.)

\begin{tabular}{|c|c|c|c|c|c|c|c|}
\hline \multirow[b]{3}{*}{$\begin{array}{l}\text { Soybean } \\
\text { genotype }\end{array}$} & \multirow[b]{3}{*}{ Disease $^{\mathrm{z}}$} & \multicolumn{6}{|c|}{ AUDPC $^{\mathrm{w}, \mathrm{x}}$} \\
\hline & & \multicolumn{3}{|c|}{ Genotype $A^{y}$} & \multicolumn{3}{|c|}{${\text { Genotype } B^{y}}^{y}$} \\
\hline & & C. g. alone & $\begin{array}{c}\text { C. g. }+1,500 \\
\text { H.g. eggs }\end{array}$ & $\begin{array}{c}\text { C. g. }+10,000 \\
\text { H. g. eggs } \\
\end{array}$ & C.g. alone & $\begin{array}{c}\text { C. g. }+1,500 \\
\text { H.g. eggs }\end{array}$ & $\begin{array}{c}\text { C. g. }+10,000 \\
\text { H. g. eggs }\end{array}$ \\
\hline BSR101 & $\begin{array}{l}\text { Incidence } \\
\text { Severity }\end{array}$ & $\begin{array}{l}83 \mathrm{a} \\
50 \mathrm{a}\end{array}$ & $\begin{array}{l}283 \mathrm{~b} \\
188 \mathrm{~b}\end{array}$ & $\begin{array}{l}505 c \\
343 c\end{array}$ & $\begin{array}{l}63 \mathrm{a} \\
48 \mathrm{a}\end{array}$ & $\begin{array}{l}297 \mathrm{~b} \\
157 \mathrm{~b}\end{array}$ & $\begin{array}{l}463 \mathrm{c} \\
316 \mathrm{c}\end{array}$ \\
\hline Jack & $\begin{array}{l}\text { Incidence } \\
\text { Severity }\end{array}$ & $\begin{array}{l}217 \mathrm{a} \\
116 \mathrm{a}\end{array}$ & $\begin{array}{l}225 \mathrm{a} \\
116 \mathrm{a}\end{array}$ & $\begin{array}{l}305 \mathrm{a} \\
155 \mathrm{a}\end{array}$ & $\begin{array}{l}275 \mathrm{a} \\
201 \mathrm{ab}\end{array}$ & $\begin{array}{l}275 \mathrm{a} \\
176 \mathrm{a}\end{array}$ & $\begin{array}{c}383 \mathrm{a} \\
277 \mathrm{~b}^{*}\end{array}$ \\
\hline Sturdy & $\begin{array}{l}\text { Incidence } \\
\text { Severity }\end{array}$ & $\begin{array}{l}409 \mathrm{a} \\
338 \mathrm{a}\end{array}$ & $\begin{array}{l}546 \mathrm{~b} \\
463 \mathrm{~b}\end{array}$ & $\begin{array}{l}703 \mathrm{c} \\
634 \mathrm{c}\end{array}$ & $\begin{array}{l}204 \mathrm{a} \\
156 \mathrm{a}\end{array}$ & $\begin{array}{l}391 \mathrm{~b} \\
294 \mathrm{~b}\end{array}$ & $\begin{array}{l}625 c \\
495 c\end{array}$ \\
\hline
\end{tabular}

${ }^{\mathrm{w}}$ Area under the disease progress curve. AUDPC $=\sum_{i=1}^{n-1}\left[\left(X_{i}+X_{i+1}\right) / 2\right]\left[t_{i+1}-t_{i}\right]$ where $X_{i}=$ disease incidence or severity expressed as a percentage of the $i$ th observation, $t_{i}=$ time (weeks after planting) at the $i$ th observation, and $n=$ total number of observations.

${ }^{x}$ AUDPC data for each cultivar were analyzed using mixed model analysis of fixed effects (Mixed Procedure) considering experiment and blocks as random effects. Treatments were compared using orthogonal comparisons. Each number is a mean from a total of 84 plants, three experiments each with four replications and one plant per replication.

y Numbers with different letters within a row are significantly different $(P<0.001, *=P \bullet 0.1)$.

${ }^{\mathrm{z}}$ C. gregata inocula were $1.5 \times 10^{9}, 1 \times 10^{8}$, and $5 \times 10^{7} \mathrm{CFU}$ of genotype A and $1.9 \times 10^{9}, 1.9 \times 10^{7}$, and $3.7 \times 10^{7} \mathrm{CFU}$ of genotype B in experiments 1,2 , and 3 , respectively. 
by genotype B with increased population density of $H$. glycines (Table 1 ).

To determine whether it is the time (intercept) or the rate (slope) of progression of colonization affected by $H$. glycines, data on incidence and severity of $C$. gregata colonization over time were also analyzed by logistic regression. Probability values for comparing differences between logistic regression parameters of pathogen treatments for each soybean cultivar are presented in Table 2.

Incidence and severity of colonization by genotype A. The higher the population density of $H$. glycines, the higher the inci-

Table 2. The $P>\chi^{2}$ for comparison of logistic regression parameters (intercepts and slopes) from analysis of incidence and severity of Cadophora gregata (C. g.) colonization in the presence of three population densities $\left(0,1,500\right.$, and 10,000) of Heterodera glycines $\left(H\right.$. g.) in growth chamber experiments ${ }^{\mathrm{y}}$

\begin{tabular}{|c|c|c|c|c|c|c|c|c|c|c|c|c|}
\hline \multirow[b]{3}{*}{ Comparison $^{\mathrm{z}}$} & \multicolumn{6}{|c|}{ Incidence of colonization } & \multicolumn{6}{|c|}{ Severity of colonization } \\
\hline & \multicolumn{2}{|c|}{ BSR101 } & \multicolumn{2}{|c|}{ Jack } & \multicolumn{2}{|c|}{ Sturdy } & \multicolumn{2}{|c|}{ BSR101 } & \multicolumn{2}{|c|}{ Jack } & \multicolumn{2}{|c|}{ Sturdy } \\
\hline & $\begin{array}{l}\text { Intercept } \\
\text { (time) }\end{array}$ & $\begin{array}{l}\text { Slope } \\
\text { (rate) }\end{array}$ & $\begin{array}{c}\text { Intercept } \\
\text { (time) }\end{array}$ & $\begin{array}{l}\text { Slope } \\
\text { (rate) }\end{array}$ & $\begin{array}{l}\text { Intercept } \\
\text { (time) }\end{array}$ & $\begin{array}{l}\text { Slope } \\
\text { (rate) }\end{array}$ & $\begin{array}{c}\text { Intercept } \\
\text { (time) }\end{array}$ & $\begin{array}{l}\text { Slope } \\
\text { (rate) }\end{array}$ & $\begin{array}{c}\text { Intercept } \\
\text { (time) }\end{array}$ & $\begin{array}{l}\text { Slope } \\
\text { (rate) }\end{array}$ & $\begin{array}{c}\text { Intercept } \\
\text { (time) }\end{array}$ & $\begin{array}{l}\text { Slope } \\
\text { (rate) }\end{array}$ \\
\hline A vs. $(\mathrm{A}+1,500)$ & $0.1006^{*}$ & 0.3583 & 0.4984 & 0.7357 & 0.2683 & 0.7483 & $0.0582 *$ & 0.1840 & 0.2016 & 0.2682 & $0.0055^{*}$ & 0.1158 \\
\hline $\begin{array}{l}\text { A vs. }(A+10,000) \\
(A+1,500) \text { vs. }\end{array}$ & $0.0899 *$ & 0.4836 & 0.2459 & 0.4497 & 0.8300 & 0.7057 & $0.0368^{*}$ & 0.1793 & 0.1259 & 0.2084 & $0.0004^{*}$ & $0.0652 *$ \\
\hline$(\mathrm{A}+10,000)$ & 0.1011 & 0.7777 & 0.1711 & 0.3266 & $0.0531 *$ & 0.5656 & $0.0165^{*}$ & 0.1561 & 0.1654 & 0.2943 & $0.0002 *$ & $0.0770^{*}$ \\
\hline $\mathrm{B}$ vs. $(\mathrm{B}+1,500)$ & 0.6839 & 0.3752 & 0.6277 & 0.3716 & 0.4749 & 0.3786 & 0.2806 & 0.9882 & 0.7516 & 0.5008 & 0.1154 & 0.8599 \\
\hline $\begin{array}{l}\text { B vs. }(B+10,000) \\
(B+1,500) \text { vs. }\end{array}$ & 0.3139 & 0.5654 & 0.8216 & 0.7149 & 0.5885 & 0.2037 & 0.1399 & 0.8172 & 0.7672 & 0.7548 & $0.0119^{*}$ & 0.4394 \\
\hline$(B+10,000)$ & 0.1726 & 0.9677 & 0.3853 & 0.7834 & 0.8002 & 0.1697 & $0.0933^{*}$ & 0.9589 & 0.4086 & 0.9161 & $0.0019 *$ & 0.1558 \\
\hline
\end{tabular}

${ }^{\text {y }}$ Numbers are $P>\chi^{2}$ from analysis of incidence and severity of $C$. gregata colonization over time by logistic regression using the Logistic Procedure. Chisquare analysis was used to test regression coefficients intercept (time) and slope (rate) differences between two pathogen treatments in a soybean cultivar $*$ statistically significant.

${ }^{\mathrm{z}} \mathrm{A}$ and B represent genotypes A and B of C. gregata, respectively; numbers 1,500 and 10,000 represent the number of $H$. glycines eggs in the treatment.

A
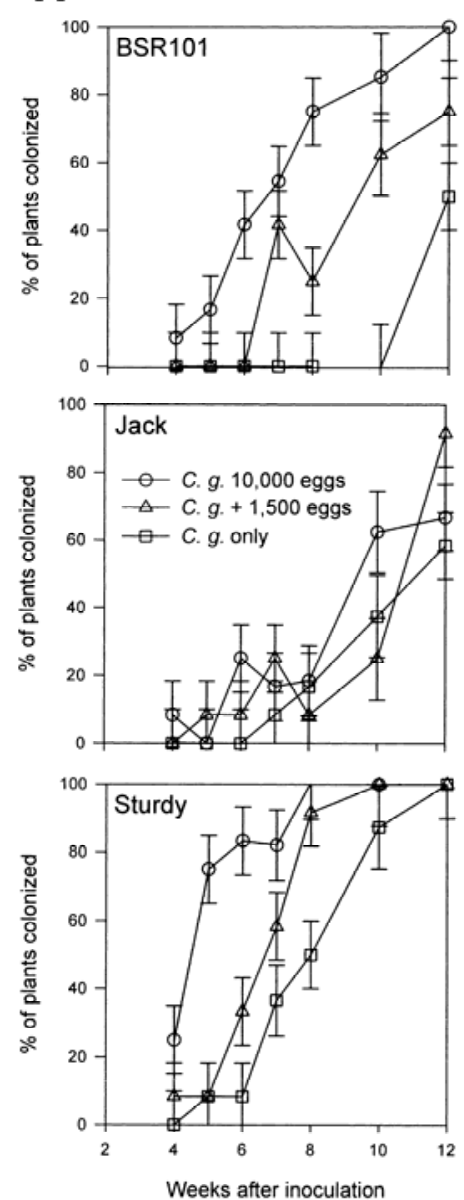

Genotype B
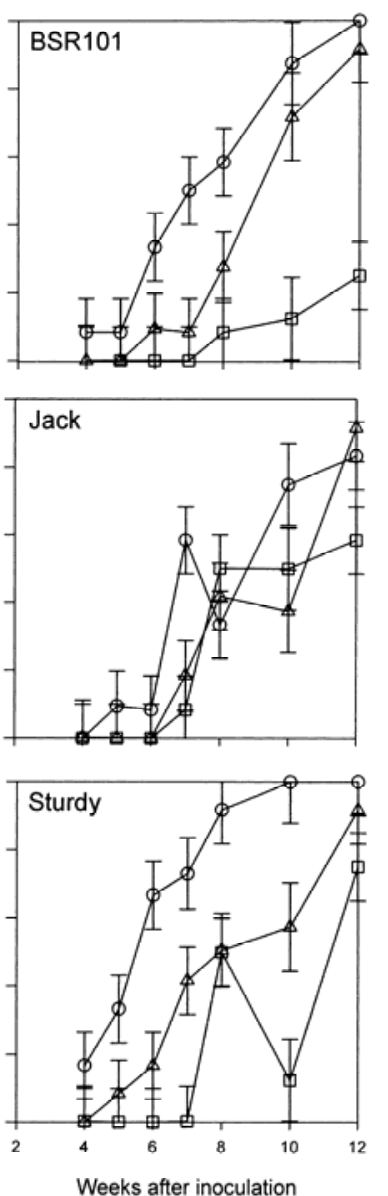

B
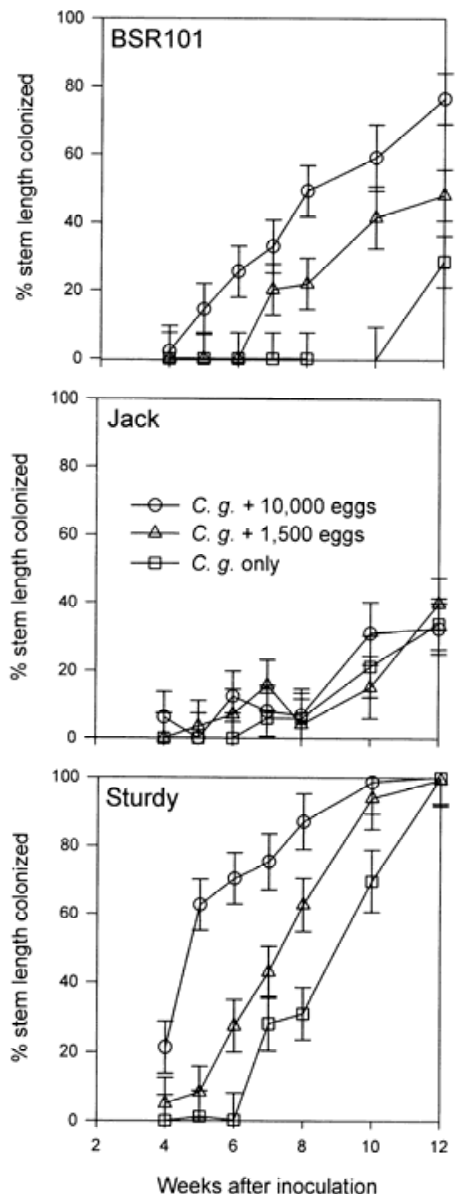

Genotype B
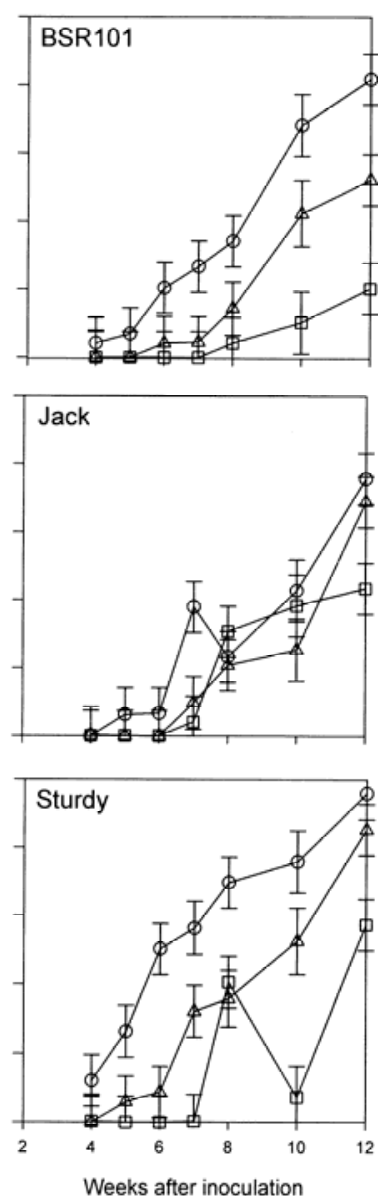

Fig. 1. A, Incidence of Cadophora gregata (C. g.) colonization of genotype A-resistant and soybean cyst nematode (SCN)-susceptible BSR101, genotype Aand SCN-resistant Jack, and genotype A- and SCN-susceptible Sturdy soybean cultivars in the absence or presence of two population densities of Heterodera glycines (H. g.) in three experiments. C. gregata inocula were $1.5 \times 10^{9}, 1 \times 10^{8}$, and $5 \times 10^{7} \mathrm{CFU}$ of genotype A in experiments $1 \mathrm{~A}, 1 \mathrm{~B}$, and $1 \mathrm{C}$, respectively, and $1.6 \times 10^{9}, 1.9 \times 10^{7}$, and $3.7 \times 10^{7} \mathrm{CFU}$ of genotype B in experiments 1A, 1B, and 1C, respectively. Data points are means of three experiments each with four replicates each with one plant. Error bars are standard errors. B, Severity of C. gregata (C. g.) colonization of genotype A-resistant and SCNsusceptible BSR101, genotype A- and SCN-resistant Jack, and genotype A- and SCN-susceptible Sturdy soybean cultivars in the absence or presence of two population densities of $\mathrm{H}$. glycines $\left(\mathrm{H}\right.$. g.) in three experiments. $\mathrm{C}$. gregata inocula were $1.5 \times 10^{9}, 1 \times 10^{8}$, and $5 \times 10^{7} \mathrm{CFU}$ of genotype A in experiments $1 \mathrm{~A}, 1 \mathrm{~B}$, and $1 \mathrm{C}$, respectively, and $1.6 \times 10^{9}, 1.9 \times 10^{7}$, and $3.7 \times 10^{7} \mathrm{CFU}$ of genotype $\mathrm{B}$ in experiments $1 \mathrm{~A}, 1 \mathrm{~B}$, and $1 \mathrm{C}$, respectively. Data points are means of three experiments each with four replicates each with one plant. Error bars are standard errors. 
dence and/or severity of colonization by genotype A in Sturdy and BSR101 but not in Jack (Fig. 1A and B and Table 2). For Sturdy and BSR101, incidence of $C$. gregata colonization occurred earlier $(P \leq$ $0.10)$ in the presence of high $(10,000$ eggs $)$ than of low (1,500 eggs) H. glycines population density (Fig. 1A and Table 2). The low $H$. glycines population density did not significantly $(P>0.10)$ increase the incidence of colonization compared with the C. gregata-only treatment in Sturdy. In BSR101, colonization occurred earlier ( $P$ $\leq 0.10)$ in the low $H$. glycines compared with the $C$. gregata-only treatment. For Jack, the incidence of $C$. gregata colonization did not increase $(P>0.10)$ in the presence of any level of $H$. glycines (Fig. 1A and Table 2).

For Sturdy, severity of $C$. gregata colonization progressed faster $(P=0.0770)$ and occurred earlier $(P=0.0002)$ in the presence of higher than of lower $H$. glycines population density (Fig. 1B and Table 2). For BSR101, severity of $C$. gregata colonization occurred earlier $(P=0.0165)$ in the presence of higher than of lower $H$. glycines population density (Fig. 1B and Table 2). In Sturdy and BSR101, the lower $(1,500)$ population density of $H$. glycines increased $(P \leq 0.10)$ severity of colonization compared with $C$. gregata-alone treatments; early severe colonization occurred. For Jack, the severity of $C$. gregata colonization did not increase $(P>0.10)$ in the presence of either low or high $H$. glycines population densities (Fig. 1B and Table 2).

Incidence and severity of colonization by genotype $B$. For all soybean cultivars tested, the incidence of $C$. gregata colonization did not progress faster $(P>0.10)$, nor did it occur earlier $(P>0.10)$ in the presence of higher than of lower $H$. glycines population density (Fig. 1A and Table 2). However, there was a trend of increased colonization with increased population density of $H$. glycines for all cultivars.

For Sturdy and BSR101, severity of $C$. gregata colonization occurred earlier $(P \leq$
$0.10)$ in the presence of high than of low H. glycines population density (Fig. 1B and Table 2). For Jack, severity of colonization by genotype $\mathrm{B}$ did not increase $(P>$ $0.10)$ in the presence of high or low $H$. glycines population density (Fig. 1B and Table 2). However, there was a trend of increased colonization by genotype B with increased population density of $H$. glycines for Jack.

\section{DISCUSSION}

We have demonstrated that with increasing population density of $H$. glycines in the soil, colonization of certain soybean cultivars by both genotypes of $C$. gregata increases (Table 1). This increase is manifested mainly as severe colonization occurring earlier in the presence of high population density than in the presence of low population density of $H$. glycines (Fig. 1B and Table 2). H. glycines-induced earlier infection by $C$. gregata may increase yield loss caused by the fungus.

Our data suggest that for the two $H$. glycines-susceptible cultivars, BSR101 and Sturdy, the incidence and/or severity of colonization of stems by both genotypes of $C$. gregata increases as the population density of $H$. glycines increases (Table 1 ). In contrast, colonization of the $H$. glycines-resistant cultivar, Jack, by both genotypes of $C$. gregata is not affected by the presence of $H$. glycines at low or high population densities. This suggests that, to manage BSR disease, it might be necessary to plant soybean cultivars with dual resistance to $H$. glycines and both genotypes of $C$. gregata.

The mechanism by which low or high $H$. glycines population densities affect the progression of colonization of soybean stems by both genotypes of $C$. gregata was not investigated in our experiments. Tabor et al. (19) has suggested mechanical wounds created by nematode activities such as movement, feeding, growth, and reproduction on soybean roots may provide a direct route for entry into the root for the fungus. Additionally, infection of soybean by $H$. glycines is known to alter photosynthesis, respiration, and nodulation caused by nitrogen-fixed bacteria (15), any of which may affect infection of the plant by the fungus. In addition, the disease defense mechanism(s) of the roots in the vicinity of wounds created by the nematode might be compromised, thus facilitating colonization of the plants by the fungus. Likewise, $H$. glycines infection might compromise the general health of the plants and adversely affect resistance to colonization by the fungus.

Genotype specificity was evident in the significant soybean cultivar $\times$ pathogen genotype interactions for incidence $(P=$ $0.0471)$ and severity $(P<0.0001)$ of colonization. Two of the three soybean cultivars did not have constant rankings when ordered according to the degree of colonization by the two genotypes of $C$. gregata (Table 3). That is, genotype $\mathrm{B}$ is more aggressive on Jack than on Sturdy, and genotype A is more aggressive on Sturdy than on Jack. Jack was more severely $(P=$ 0.0200) colonized by genotype B than by genotype A. Conversely, Sturdy was more frequently $(P=0.0110)$ and severely $(P<$ 0.0001 ) colonized by genotype A than by genotype B. For BSR101, there was no difference either in incidence or severity of colonization between genotype A and B. It has been reported that, under field conditions, soybean varieties derived from the same source of BSR resistance as Jack are colonized more frequently by genotype B than by genotype A (11). One such cultivar is Bell; of 87 stem samples collected from plants grown on soil naturally infested with both genotypes A and B, $99 \%$ of the stem samples from Bell tested positive for genotype B and $1 \%$ for genotype A. The corresponding numbers for sturdy were $57 \%$ genotype A and $43 \%$ genotype B (11).

Our results have implications for both growers and BSR researchers. The sources of BSR resistance in the soybean genotypes tested in our experiments are similar to the sources of BSR resistance in most currently available commercial cultivars. Consequently, cultivars with resistance

Table 3. Reaction of soybean cultivars to genotypes A and B of Cadophora gregata in growth chamber experiments

\begin{tabular}{|c|c|c|c|c|c|c|c|c|}
\hline \multirow{3}{*}{$\begin{array}{l}\text { Soybean } \\
\text { cultivar }\end{array}$} & \multicolumn{4}{|c|}{ AUDPC $^{\mathbf{w}, \mathbf{x}}$} & \multicolumn{4}{|c|}{$\operatorname{Rank}^{y}$} \\
\hline & \multicolumn{2}{|c|}{ Incidence $^{\mathrm{z}}$} & \multicolumn{2}{|c|}{ Severity ${ }^{z}$} & \multicolumn{2}{|c|}{ Incidence $^{y}$} & \multicolumn{2}{|c|}{ Severity ${ }^{y}$} \\
\hline & Genotype A & Genotype B & Genotype A & Genotype B & Genotype A & Genotype B & Genotype A & Genotype B \\
\hline BSR101 & $83 \mathrm{a}$ & $63 \mathrm{a}$ & $50 \mathrm{a}$ & $48 \mathrm{a}$ & 1 & 1 & 1 & 1 \\
\hline Jack & $217 \mathrm{a}$ & $275 a$ & $116 \mathrm{a}$ & $201 \mathrm{~b}$ & 2 & 3 & 2 & 3 \\
\hline Sturdy & $409 a$ & $204 \mathrm{~b}$ & $338 \mathrm{a}$ & $156 \mathrm{~b}$ & 3 & 2 & 3 & 2 \\
\hline
\end{tabular}

w Area under the disease progress curve. AUDPC $=\sum_{i=1}^{n-1}\left[\left(X_{i}+X_{i+1}\right) / 2\right]\left[t_{i+1}-t_{i}\right]$ where $X_{i}=$ disease incidence or severity expressed as a percentage of the $i$ th observation, $t_{i}=$ time (weeks after planting) at the $i$ th observation, and $n=$ total number of observations.

${ }^{x}$ AUDPC data for each cultivar were analyzed using mixed model analysis of fixed effects (Mixed Procedure) considering experiment and blocks as random effects. Treatments were compared using orthogonal comparisons. Each number is derived from a total of 84 plants, three experiments each with four replications and one plant per replication.

y Rankings of three cultivars ( 1 = least colonized and $3=$ most colonized $)$ based on AUDPC values for incidence and severity of colonization by each genotype of $C$. gregata (without $H$. glycines) presented in left-hand side of this table.

${ }^{\mathrm{z}}$ Numbers with the same letter within a row are not significantly $(P<0.05)$ different from each other. 
only to $C$. gregata may be ineffective for management of brown stem rot disease in fields infested with $C$. gregata and high population densities of $H$. glycines. It is important, however, to note that our data are from growth chamber experiments with a limited range of soybean cultivars and pathogen populations and population densities. Thus, whether $H$. glycines, at any population density level, results in earlier infection by $C$. gregata under field conditions is yet to be tested.

\section{ACKNOWLEDGMENTS}

This research was supported by Hatch Act (Project No. 3288) and State of Iowa funds and a grant from the North Central Soybean Research Program. We thank Philip Dixon and Paul Esker, Departments of Statistics and Plant Pathology, respectively, Iowa State University, for assistance in statistical analysis, and our colleagues in the Department of Plant Pathology, D. H. Soh and C. C. Marett, for technical assistance.

\section{LITERATURE CITED}

1. Allington, W. B., and Chamberlain, D. W. 1948. Brown stem rot of soybean. Phytopathology 38:793-802.

2. Campbell, L. C., and Madden, L. V. 1990. Introduction to Plant Disease Epidemiology. John Wiley \& Sons, New York.

3. Chen, W., Grau, C. R., Adee, E. A., and Meng, X.-Q. 2000. A molecular marker identifying subspecific populations of the soybean brown stem rot pathogen, Phialophora gregata. Phytopathology 90:875-883.

4. Gerdemann, J. W. 1955. Relation of a large soil-borne spore to phycomycetous mycorrhizal infections. Mycologia 47:619-632.

5. Harrington, T. C., and McNew, D. L. 2003. Phylogenetic analysis places the phialophoralike anamorph genus Cadophora in the
Helotiales. Mycotaxon 87:141-151.

6. Harrington, T. C., Steimel, J., Workneh, F., and Yang, X. B. 2003. Characterization and distribution of two races of Phialophora gregata in the North-Central United States. Phytopathology 93:901-912.

7. Hosmer, W. D., and Lemeshow, S. 2000. Applied Logistic Regression. 2nd ed. John Wiley \& Sons, New York.

8. Hughes, T. J., Chen, W., and Grau, C. R. 2002. Pathogenic characterization of genotypes A and B of Phialophora gregata f. sp. sojae. Plant Dis. 86:729-735.

9. Jenkins, W. R. 1964. A rapid centrifugalfloatation technique for separating nematodes from soil. Plant Dis. Rep. 48:692.

10. Little, R. C., Wolfinger, R. D., Stroup, W. W., and Milliken, G. A. 1999. SAS System for Mixed Models. SAS Institute, Cary, NC.

11. Malvick, D. K., Chen, W., Kurle, J. E., and Grau, C. R. 2003. Cultivar preference and genotype distribution of the brown stem rot pathogen Phialophora gregata in the midwestern United States. Plant Dis. 87:1250-1254.

12. Negishi, H., and Kobayashi, K. 1984. Effect of soybean cyst nematode on the incidence of brown stem rot (BSR) of adzuki bean. Ann. Phytopathol. Soc. Jpn. 50:500-506.

13. Niblack, T. L., Heinz, R. D., Smith, G. S., and Donald, P. A. 1993. Distribution, density, and diversity of Heterodera glycines in Missouri. J. Nematol. 25:880-886.

14. Nickell, C. D., Noel, G. R., Thomas, D. J., and Waller, R. 1990. Registration of 'Jack' soybean. Crop Sci. 30:1365.

15. Noel, G. R. 2004. Soybean response to infection. Pages 132-151 in: Biology and Management of Soybean Cyst Nematode, 2nd ed. D. P. Schmitt, J. A. Wrather, and R. D. Riggs, eds. Schmitt and Associates of Marceline, Marceline, MO.

16. Orf, J. H., Lambert, J. W., and Kennedy, B. W. 1991. Registration of 'Sturdy' soybean. Crop Sci. 31:486-487.

17. Riggs, R. D., and Wrather, A. J. 1992. Biology and Management of the Soybean Cyst Nematode. American Phytopathological Society, Saint Paul, MN.

18. Sugawara, K., Kobayashi, K., and Ogoshi, A. 1997. Influence of the soybean cyst nematode (Heterodera glycines) on the incidence of brown stem rot in soybean and adzuki bean. Soil Biol. Biochem. 29:1491-1498.

19. Tabor, G. M., Tylka, G. L., Behm, J. E., and Bronson, C. R. 2003. Heterodera glycines infection increases incidence and severity of brown stem rot in both resistant and susceptible soybean. Plant Dis. 87:655-661.

20. Tabor, G. M., Tylka, G. L., Cianzio, S. C., and Bronson, C. R. 2003. Resistance to Phialophora gregata is expressed in the stems of resistant soybeans. Plant Dis. 87:970-976.

21. Tachibana, H., Voss, B. K., and Fehr, W. R. 1987. Registration of 'BSR 101' soybean. Crop Sci. 27:612.

22. Tubajika, K. M., Tylka, G. L., Tachibana, H., and Yang, X. B. 1994. Incidence of brown stem rot as influenced by soybean cyst nematode. (Abstr.) Phytopathology 84:1101.

23. Tylka, G. L. 1995. Soybean cyst nematode. Iowa State University, Ext. Publ. Pm-879. ISU, Ames, IA.

24. Tylka, G. L. 2004. Soybean cyst nematoderesistant varieties for Iowa. Iowa State University, Ext. Publ. Pm-1649. ISU, Ames, IA

25. Workneh, F., Tylka, G. L., Yang, X. B. Faghihi, J., and Ferris, J. M. 1999. Regional assessment of soybean brown stem rot, Phytophthora sojae, and Heterodera glycines using area-frame sampling: Prevalence and effects of tillage. Phytopathology 89:204-211.

26. Wrather, J. A., Koenning, S. R., and Anderson, T. 2003. Effect of diseases on soybean yields in the United States and Ontario 1999-2002. Online. Plant Health Progress DOI:10.1094/ PHP-2003-0325-01-RV

27. Yang, X. B., and Lundeen, P. 1997. Soybean brown stem rot. Iowa State University, Ext. Publ. Pm-890. ISU, Ames, IA. 